\title{
4
}

\section{Positive Youth Development in Education}

\author{
Daniel Romer and David Hansen
}

There has been growing interest in positive youth development (PYD) as an approach to promoting the health and welfare of young people. This interest derives from the realization that there is more to understand regarding healthy development than there is from concerns about reducing risky behaviour or mental illness, both of which increase during adolescence and draw most of the attention of parents, policymakers, and the general public. With these problems at the forefront of attention, it is perhaps not surprising that researchers have devoted a large share of their attention to these concerns. However, there is increasing recognition that the mere absence of risk behaviours or mental illness is not synonymous with developmental success (Benson, Scales, Hamilton, \& Sesma Jr, 2007), which Pittman and Fleming (1991) poignantly summarized with the maxim problem-free is not fully prepared.

PYD has always been grounded in practice first, with research following in the 1990s to ostensibly provide empirical support for PYD practices based on the wealth of existing practitioner expertise (Lerner et al., 2018; Zeldin, 2000). Within the PYD framework, developmental success represents progress towards becoming a fully functioning adult with the abilities and

D. Romer $(\varangle)$

University of Pennsylvania, Philadelphia, PA, USA

e-mail: dan.romer@appc.upenn.edu

D. Hansen

University of Kansas, Lawrence, KS, USA 
competencies to reach one's potential while also contributing to the welfare of the community. Certainly health-compromising behaviour habits or mental illness can derail progress towards developmental success, but their absence alone does not define it. Similarly, an inordinate focus on problem prevention can only provide minimal insight into the factors that lead to positive development. PYD represents a shift in how we conceptualize the "positive" in youth development, which can ultimately lead to insights into how to promote developmental success including reduction in health-compromising outcomes.

\section{What Is Positive Youth Development?}

PYD as a field is a loose collection of a wide range of stakeholders (e.g., academic disciplines and practice) across many areas connected by philosophical ideals. The nature of PYD as a collective means there is no single theoretical model that drives the field, yet despite this, there are common conceptual and theoretical principles that unify this multidisciplinary field.

Core theoretical tenets of PYD have been embedded within developmental and psychological sciences, which view development resulting from a complex interaction between individuals and the contexts in which they reside (Lerner, 1998). At the individual level, PYD theory asserts that individuals seek to be intentional, active agents or producers of their development (Larson, 2000; Lerner, Theokas, \& Jelicic, 2005). That is, within the PYD framework every person has an inherent capacity for positive growth-to exercise personal agency-that pushes them to develop skills and competencies consonant with their goals.

Youth, as active agents, are also embedded within a community with various contexts, ecologies, and relationships from which they select to prioritize personal development (Benson et al., 2007). A positive developmental trajectory occurs when these various settings support or nurture individuals' agency as producers of their own development (Duerden, Widmer, \& Witt, 2017). In addition, positive development is further enhanced when individuals are involved in multiple and, ideally, interconnected, supportive settings within a community. Community, then, is an important mechanism through which positive development occurs.

In this chapter we review the various research streams stemming from PYD that have sought to understand the factors that promote positive development especially as they apply to both formal and informal education. We begin with a review of the philosophical ideas that have foreshadowed much 
of this research, namely the writings of Aristotle. His ideas not only provide a blueprint for many of the theories advanced to study PYD but also for questions that could receive more attention. PYD is a loosely connected field of research and practice guided to these philosophical ideals rather than a tightly orchestrated agenda. As such, we review a broad base of research, theory, and practice, with an eye towards educational application.

\section{Philosophical Roots of PYD}

Aristotle's theories of human development have not only animated recent approaches to PYD but have been a long-standing influence on the evolution of democratic rule in the Western world. Aristotle's theory of happiness as the ultimate objective of life played a large role in subsequent theories of human rights as exemplified by the U.S. Declaration of Independence and Constitution in which the "pursuit of happiness" was a motivating force. His focus on living a virtuous life was also a source of inspiration for the development of public education in America. It is critical therefore to unwrap what Aristotle meant by happiness and virtue because these concepts have been subject to different interpretations. In addition, despite his inspiration for modern discussion of wellbeing and positive development, his ideas have not always been faithfully interpreted, as we describe below.

The term used by Greek philosophers to connote happiness was eudaimonia, which literally means good spirit. Aristotle's (1999) theory of happiness was laid out in his Nichomachean Ethics, a rather compact tome that has been translated many times in different languages. It is believed that he titled the book after his son, Nichomachas, and intended the book to be a guide for life. For Aristotle, happiness is the ultimate objective of life because achieving it is sufficient to itself. Acting in ways that promote happiness is therefore living a good life. Pursuing one's goals, such as having a significant other in one's life, raising children, and contributing to one's community are all virtuous pursuits, as is perfecting one's talents. But the way in which one does these things also matters, which is why he argued that living the good life meant living "in accord with the virtues" (p. 1099a, 21).

An important distinction in Aristotle's thinking was the difference between seeking pleasure and seeking happiness. Pleasure can certainly be an important by-product of happiness, but it is not the objective. This is easy to see in that one can gain pleasure from doing things that are harmful to others and oneself. Since seeking pleasure is not a sign of virtue, maximizing pleasure cannot be the ultimate objective of living a good life. This view of 
seeking happiness rather than pleasure differs from an approach to decisionmaking in daily life that emphasizes the hedonistic outcomes of behaviour that underlie many approaches to both psychology and economics. Aristotle rejected the hedonistic approach by focusing on the virtuous sources of decision-making. He thus linked the happy life to the ethical life.

Aristotle argued that people should strive to live a life that exemplifies universal virtues, including what he called the major virtues of character: justice, temperance, and courage. He saw these goals as the basis of ethics, which are closely related to the Greek term for character (ethos). One acts with justice by treating others with fairness and respect. One acts with temperance by steering away from maximizing pleasure and avoiding pain as the main criteria for decisions in life: what we now call self-regulation. Finally, one acts with courage by standing up for oneself and one's ideals and not fearing the pursuit of difficult goals, which shares similarities with modern conceptualizations of personal agency.

For Aristotle, pursuing virtue requires moderation. That is, if one only wants to maximize pleasure and avoid pain, then one will ignore the virtues of justice, temperance, and courage. For example, one will cheat others to gain an advantage, or become angry when something disappoints, or be afraid to stand up for one's rights. In each case, one is encouraged to follow the middle path, which will lead to virtue but not necessarily the most pleasant path. The path of moderation also leads to pursuing goals that are worthy for their own sake rather than to please others. This concept is evident in theories that emphasize what is now called intrinsic motivation.

Aristotle also prized what he called virtues of reason, such as prudence, which entails careful deliberation to consider the consequences of one's actions for both oneself and others to reach good decisions before acting. The prudent person considers the particulars of a decision so that one can satisfy the virtues while also achieving one's goals. As one matures, one also gains practical wisdom, which is knowing how to confront challenging ethical decisions (Wren, 2014).

In order to cultivate a virtuous life, Aristotle placed responsibility on parents and adults in the community to train its youth to recognize and develop the character of a virtuous person and the reasoning skills of the prudent person. In proposing the virtuous life as the guide to behaviour, Aristotle effectively linked ethics to character. Linking ethics to character development also has implications for positive development with his suggestion that the best way to develop a virtuous life is to practice acting in a virtuous manner. Aristotle viewed such practice as a necessary step to developing a virtuous character since virtuous character was unlikely to come 
naturally. The best way to cultivate virtuous character required practice with the support and guidance of adults (see also Sherman, 1991).

Aristotle also emphasized the importance of politics as a source of virtue. The political system in his view has the responsibility of fostering virtue in its citizens, and thus an important part of this responsibility is the education of the young to appreciate the virtues of good government. The body politic also has the responsibility of enacting laws that will be beneficial to the public. This idea also was appreciated in America's movement towards public education in that it was hoped that universal education would inculcate the virtues of citizenship in young people. Horace Mann, the father of public education in the U.S., was a firm believer in the importance of the pursuit of happiness as a "law of our nature" and advocated for a system of public education that should have as its aims "social efficiency, civic virtue, and character..." (Cubberley, 1919, p. 167). John Dewey (1961) elaborated on this theme with his advocacy for democratic schools that enable the individual to become an active participant in democracy.

Finally, Aristotle emphasized the importance of relationships, especially friendships, as a key component of a happy life. In his view, connection with others who can share in the virtuous life enhances the ability of the individual to do so as well.

\section{From Philosophical Ideals to Contemporary Views of Happiness}

Aristotle's conceptualization of happiness, with an emphasis on a virtuous life lived in connection with society, can be clearly seen in contemporary PYD concepts and frameworks. Before considering how PYD embodies Aristotle's conception of happiness, we contrast his eudemonic interpretation of happiness with some current approaches to happiness associated with the positive psychology movement, some of which focus more heavily on the hedonic aspects of happiness, such as the successful pursuit of pleasure.

\section{Happiness and Positive Psychology}

Achieving happiness has become a subject of great popular interest, which is partly a result of the emergence of positive psychology as a discipline. Led by Martin Seligman (Forgeard, Jayawickreme, Kern, \& Seligman, 2011; Seligman \& Csikszentmihalyi, 2000), this approach explicitly focuses on the 
factors that Aristotle noted as promoting a happy life, including the recognition of virtue and character strengths as guides to happiness (Peterson $\&$ Seligman, 2004) and the practice of virtuous habits, such as showing gratitude to those who have helped us rather than dwelling on the disappointments that may have hindered our success.

Despite the influence of Aristotle's conception of happiness, the pursuit of pleasure has remained a feature of positive psychology. In a review of the concept of happiness, Seligman and colleagues (Forgeard et al., 2011) suggested that a useful way to define happiness is to consider it as a form of wellbeing or flourishing with five components: positive emotion, engagement, relationships, meaning, and accomplishment or PERMA. These five elements "are the best approximation of what humans pursue for their own sake" (p. 97) They proposed that this definition includes both hedonic and eudemonic perspectives and therefore provides a more complete picture of what one means by happiness.

Another approach proposed by Keyes (2007) following on Ryff (1989) overlaps with Seligman and colleagues' focus on positive emotion, but it includes a variety of other factors that overlap with achievement and meaning, such as purpose in life, self-acceptance, positive relationships, and personal growth. As these approaches suggest, positive affect and emotion are considered prominent features of happiness. However, the field of PYD has tended to view these features as more of an effect of PYD than a motivator for development, as we illustrate next.

\section{Eudemonic Versus Hedonic Approaches to Happiness}

The conflict between the eudemonic and hedonic approaches to happiness has received considerable attention in psychology (e.g., Kashdan, BiswasDiener, \& King, 2008; Ryan \& Deci, 2001; Waterman, 2007). This is perhaps sparked by some strands of positive psychology that have equated happiness with pleasure in the sense of maximizing pleasant affect and satisfaction with life: for example, the approach to wellbeing promoted by Diener et al. (2006). This approach de-emphasizes Aristotle's view that happiness is necessarily linked to living a virtuous life. The disregard for virtue may reflect the desire to measure happiness as defined by the individual rather than as defined by theories of virtue (Kashdan et al., 2008). Asking people how satisfied they presently are with their lives or how much pleasant affect they have recently experienced assesses wellbeing without constraining its definition. When this is done, there is an interesting U-shaped relation between satisfaction and age, with satisfaction starting to decline in adolescence and not 
returning to its early level until late in life (see Fig. 4.1; Qu \& de Vaus, 2015). If this definition is correct, then people are less than happy throughout most of their adult lives. A recent international study of life satisfaction (Jebb et al., 2020) confirmed this pattern of life satisfaction declining relative to age 20 in most regions of the world. But it is reasonable to expect that happiness in Aristotle's terms will increase during the lifespan as people gain wisdom and experience acting in accord with the virtues.

When people are surveyed using a measure more in line with Aristotle, a different pattern appears. In a study by Steger et al. (2009), the authors conducted a large online survey of persons ages 18-70 that examined age differences in happiness that asked about the presence of meaning in one's life (e.g., I have a good sense of what makes my life meaningful) and the search for meaning in one's life (e.g., I am seeking a purpose or mission for my life). Trends in these measures were different from what was reported in Fig. 4.1. During the early adult period (ages 18-44), there was a decline in the presence of meaning and high levels of search for meaning. However, for older adults, achieving meaning increased with age while the search for it declined. Although ratings of satisfaction comparable to those taken in Fig. 4.1 were

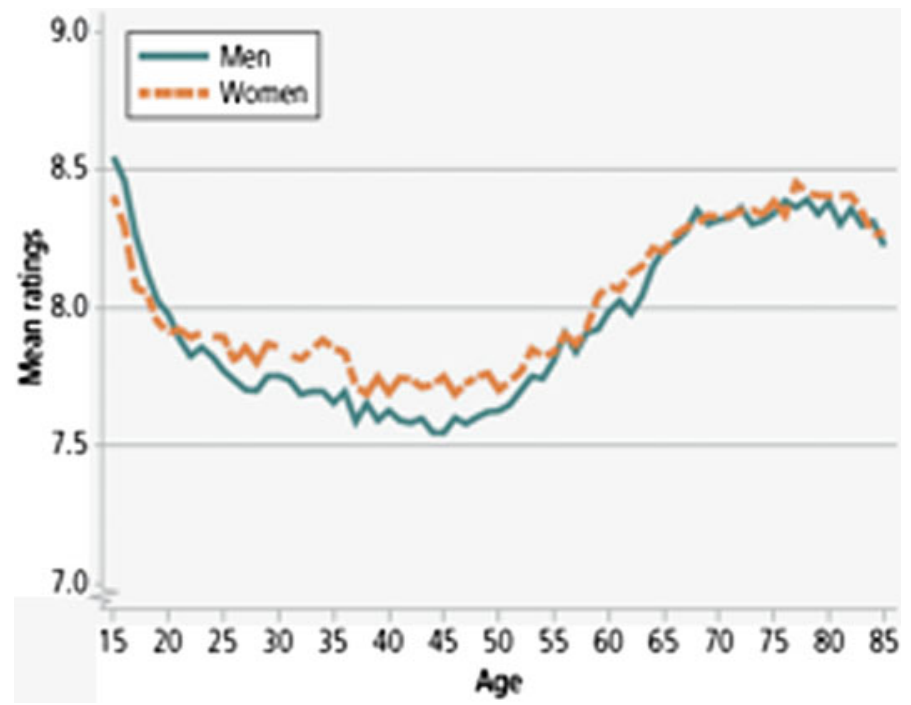

Fig. 4.1 Mean ratings of life satisfaction on a scale from $0=$ completely dissatisfied to $10=$ completely satisfied, by age and gender from 2001 to 2012 in Australia (Original image published in Qu, L., \& de Vaus, D. [2015]. Life satisfaction across life course transitions [Australian Family Trends, No. 8; p. 14], by Australian Institute of Family Studies. This image is licensed under an All Rights Reserved License, and is not available under a Creative Commons license) 
positively related to the discovery of meaning (at about $r=.60$ ), the age trends were different, suggesting that for meaning, once one enters middle age at about age 45 , there is a steady increase in reports of meaning and a steady decline in the search for it, with both trends exceeding the levels observed in early adulthood (higher for presence and lower for search). These trends are more in line with what one would expect from an Aristotelian perspective towards happiness. They suggest that although we are not as satisfied with our lives as we progress from adolescence, this is more a result of our search for purpose than a source of disappointment. The findings also suggest that the search for meaning in early development provides opportunities for youth centred programs to facilitate the discovery of such meaning for each individual.

\section{A Eudemonic Approach in Psychology}

Because the virtues are a form of excellence in action and reasoning that spring from one's unique interests and talents, theories that focus on intrinsic motivation are adopting this line of thought. The perhaps most welldeveloped psychological theory of intrinsic motivation is Deci and Ryan's Self-Determination Theory (SDT) (Ryan \& Deci, 2000; Shogren \& Little, 2017). They argued that to encourage learning and adaptive decision-making, one should use strategies that enable youth to follow their own interests in a supportive environment that promotes what they called autonomy. An environment that promotes autonomy enables parents, adults and communities to encourage development of curiosity and self-determination in youth. In short, activities that evoke the most passion (i.e., intrinsic motivation) will be the most fulfilling.

Aristotle's virtue of prudence can be seen in Deci and Ryan's focus on the importance of competencies to achieve one's goals. Competency involves learning basic skills of decision-making, as well as other skills, so that one can best achieve one's goals. And finally, they suggested that people have a need for relatedness or connection with others in order to become fully selfdetermined actors, which follows from the importance of justice along with parenting and friendship as important sources of upbringing and virtue.

Despite the reliance on eudemonic principles, Deci and Ryan do not emphasize the virtues as a source of happiness. Nevertheless, their theory does link with some of the major principles of PYD, as we illustrate below. The theory also emphasizes the importance of action and prudence as sources 
of happiness, which is related to Aristotle's notion of good character and reasoning as the embodiment of virtue.

\section{Current Embodiments of Eudaimonia in Positive Youth Development}

\section{The 5C's Plus Contribution}

As noted, training to develop a virtuous character requires practice in the actions that comprise virtue. A leading model of PYD focuses on what is termed the five C's plus contribution popularized by Pittman et al. (2000) and others (Lerner et al., 2000; Roth \& Brooks-Gunn, 2003): connection, competence, character, caring, confidence, and contribution. Lerner (2004) made contribution the centrepiece of his theory of thriving. Programs and policies that advance these objectives of development tend to focus on one or more, but they all tend to touch on at least one.

- Connection. PYD is facilitated by strong guidance and bonding with parents and other adults in one's community. Bonding with parents during childhood is a powerful factor in healthy development, and the ability to form close supportive relationships with parents, peers, and adults is integral for developing virtuous habits. This characteristic plays out in schools where positive climates between students and teachers are thought to encourage respect for the individual and foster academic achievement. It also applies to other community settings, such as out-of-school programs.

- Competence. Building agentic and adaptive decision-making skills is a cornerstone of PYD. This has been an important factor in many school programs that aim to encourage healthy development and to prevent problem behaviour. Included in these programs are specific skills that further the virtue of temperance which includes self-control over impulses and the ability to cooperate with peers.

- Character: This aspect of PYD reflects the person's ability to recognize and be sensitive to the virtues in oneself and others, including the three main virtues of justice, temperance, and courage.

- Caring: This aspect of character emphasizes the importance of sensitivity to the needs of others, which is closely aligned with justice, respect for others, and generosity.

- Confidence: This is the virtue of courage to believe in oneself and to stand up for the ideals that one holds dear. 
- Contribution: This is the desire to make one's community stronger and to the fostering of virtues in the community. This element is considered a consequence of the 5Cs and is often studied as such. It is also embodied in the notion of the virtuous citizen whose strengths can be cultivated through programs of PYD (Lerner, 2004).

While PYD does not explicitly focus on happiness as an objective, the promotion and development of the above strengths is consistent with the acquisition of habits that lead to happiness in the eudemonic sense. The absence of any mention of life satisfaction or positive emotion is perhaps what distinguishes the PYD approach from some elements of positive psychology as an approach to youth and adult development.

\section{Assessment of the " 5 C's Plus" Contribution}

The 5C's not only serve as aspirations for PYD programs, they have also been measured in programs designed to advance PYD objectives. Lerner and colleagues have developed self-report assessments of the 5C's that have high reliability and appear to be explained by a higher-order PYD factor (Geldhof et al., 2014; Lewin-Bizan et al., 2010). The samples for this research were recruited in a longitudinal study of the 4- $\mathrm{H}$ program for youth discussed below. In the more recent study by Geldhof et al. (2014), the sample of 7071 youth spanned the entire range of the study from 5th to 12 th grade. The higher-order PYD factor was positively correlated at all grades along with a measure of contribution. In addition, the scale was inversely related to a measure of depressive symptoms and problem behaviours. In Lewin-Bizan et al. (2010), trajectories of the PYD factor indicated that for most of the youth attending the $4-\mathrm{H}$ program $(67 \%)$, PYD increased from 5 th to 10 th grade. A small group (6\%) exhibited declines.

A study conducted with students ages 11-19 in the Republic of Ireland also found support for the presence of a higher order PYD factor in both younger and older students (Conway et al., 2015). In this sample, there was also evidence that younger students (ages 11-14) had higher PYD scores than older students (ages 15-19). Nevertheless, the finding that PYD was positively related to a measure of contribution and negatively related to a measure of depressive symptoms and risk behaviour was replicated for both age groups. 


\section{Developmental Assets and Thriving}

Another embodiment of PYD focuses on developmental assets as the building blocks of thriving in adolescents and young adults (Scales, Benson, \& Leffert, 2000; Scales et al., 2016). The assets approach has been studied in large surveys of adolescents by researchers at the Search Institute (https://www.sea rch-institute.org/). They defined thriving as encompassing seven outcomes: School success is seen as evidence of striving for excellence, while being a leader, helping others and valuing diversity are signs of caring. The ability to delay gratification and to maintain good physical health are signs of the ability to selfregulate and make healthy decisions. Finally, the ability to overcome adversity can be seen as a sign of courage.

With these outcomes in mind, Scales and colleagues (Lefferts et al., 1998) proposed eight potential overarching assets that would enable a young person to thrive. These included four external assets: support from family and others in the community, empowerment in the community, boundaries and expectations for safe behaviour, and the presence of youth programs that promote constructive use of time. An additional four personal assets were seen as critical to thriving: commitment to learning, positive values that exemplify virtuous behaviour (e.g., honesty, caring, justice), social competencies such as good decision-making skills, and a positive identity that includes a sense of purpose in life and a positive view of the future.

In the first large-scale evaluation of the assets framework, Lefferts et al. (1998) administered a survey to 99,462 youth in grades 6 through 12 that assessed self-reports of the various assets and indicators of thriving. It was noteworthy that external assets tended to decline from middle to high school. For example, family support was endorsed by $71 \%$ of boys and girls in middle school but only by 59 and $60 \%$ of boys and girls respectively in high school. There was more heterogeneity in developmental change in internal assets. Most remained at about the same levels, but in some cases, there were declines, such as for restraint (from 53 to $25 \%$ in boys and from 67 to $36 \%$ in girls), perhaps reflecting the increasing tendency for exploration in adolescence.

Despite the age differences, many of the assets were inversely related to various risky behaviours, such as the use of drugs and other anti-social activities. This finding is consistent with the argument that PYD is protective for the development of unhealthy behaviour in adolescence. There was also evidence that many assets were protective against depression and suicidal ideation. 
A later study examined the relation between assets and indices of thriving in a subsample of 6000 youth of the Lefferts et al. (1998) study (Scales, Benson, et al., 2000). In general, regarding thriving indicators, high school youth were less likely to affirm support for diversity than middle school students, male students were more likely to report overcoming adversity, and older students also reported overcoming adversity more than younger students. Regarding overall assets, the stronger the assets that students reported, the more likely they were to report indicators of thriving: school success, overcoming adversity, maintaining health, and delaying gratification. The various assets explained about $50 \%$ of the variance in thriving apart from demographic differences, and this pattern held for all of the various racial and ethnic groups that were included in the sample. Curiously, developmental assets accounted for less of the overcoming adversity indicator than of the other measures of thriving.

Scales et al. (2000) also examined an important tenet of PYD-that development is enhanced when individuals are embedded within multiple supportive contexts in a community. Consistent with this tenet, the amount of time youth spent in out-of-school programs correlated consistently and relative strongly with most of the thriving outcomes. Scales et al. interpreted this as a result of the many out-of-school programs basing their practices on PYD principles, such as "access to caring adults and responsible peers, as well as skill building activities that can reinforce the values and skills that are associated with doing well in school and maintaining good physical health. Further, youth programs may provide more opportunities than other contexts for youth to serve in leadership roles" (p. 43).

In a more recent analysis of the assets approach for the transition to adulthood, Scales et al. (2016) noted the apparent decline during high school in students' perceptions of external assets. Based on these findings, they suggested that adolescents in the U.S. are not well prepared to make the difficult transition to adulthood.

In summary, two dominant approaches to PYD that are consistent with a eudemonic approach to happiness have defined major components of this concept and have developed self-report assessments that have been successfully administered to middle and high school youth. This research has made strides in defining the elements of PYD, but it has not identified the educational components that can promote PYD. It is to these approaches that we turn next. 


\section{Educational Approaches to PYD}

\section{Social-Emotional Learning}

Social-emotional learning (SEL) has become the most well-known approach to PYD in the U.S. It encompasses a variety of programs to develop social and reasoning skills primarily for elementary and middle school contexts. This approach follows a long tradition focused on the importance of adaptive decision-making (e.g., judgement and decision-making; Klaczynski, 2005), which is also a cornerstone of Aristotle's reasoning virtues. The virtuous decision maker learns to generate alternative solutions to any problem and to evaluate the solutions with regard to likely outcomes. Furthermore, in considering consequences, one needs to consider their effects on others, especially their welfare in addition to that of the actor. This paradigm has been widely followed in programs that encourage adaptive problem-solving. For example, one of the earliest is the I Can Problem Solve approach of Shure and Spivack (1982) designed for use in preschool to grade 6 to encourage adaptive responses to common conflicts, such as sharing of resources or confronting bullying (Shure, 2001, 2003).

Effective problem-solving strategies are also central to the development of self-determination because they enable the individual to exert control over the process of making difficult decisions. These strategies also focus on emotional self-regulation to regulate one's temper as well as to recognize others' feelings. Thus, it is not surprising that these strategies are fundamental to school programs that develop competencies in what has become known as social-emotional learning.

According to Durlak, Weissberg, Dymnicki, Taylor, and Schellinger (2011), youth in SEL programs are taught how to acquire "core competencies to recognize and manage emotions, set and achieve positive goals, appreciate the perspectives of others, establish and maintain positive relationships, make responsible decisions, and handle interpersonal situations constructively" (p. 406). These competencies are clearly valuable, and this has given the approach much of its appeal. In addition, the meta-analysis of Durlak et al. (2011) indicated that programs that developed these skills also enhanced academic outcomes, which also added to its appeal. Kern et al. (2017) provided an overview of the various evaluations of these programs which have tended to show favourable outcomes in terms of better school achievement and fewer unhealthy behaviours in elementary and middle schools.

The challenge that such a broad set of goals raises, however, is how to adapt the educational mission and curricula of schools to achieve them. Some 
programs have focused heavily on training the various skills that are encompassed by SEL isolated from a school's curriculum without considering how the training can best be integrated into the school curriculum. Attempting to teach SEL skills in isolation has created a somewhat unrealistic expectation about the ability of SEL programs to produce the results promised, such as improved academic achievement. As a result, many programs that claim to train SEL skills may do so without integrating them into the school's educational practices and, consequently, there is considerable variation in outcomes. For example, while it is expected that developing SEL competencies should reduce anti-social behaviour such as bullying, not all programs have been successful in this endeavour (Jones et al., 2017). SEL programs have also been more easily adapted for younger children than for adolescents (Yeager, 2017), perhaps because adolescents require a greater degree of respect for their autonomy than typical SEL training allows.

Although meta-analyses of SEL programs in schools tend to show favourable effects, many of the studies have not employed random assignment to conditions, nor have they validated assessments across all of the outcomes that are expected to be improved by SEL training. In response, the U.S. Department of Education undertook an intensive evaluation of seven programs that were regarded as having a strong evidence base (Social and Character Development Research Consortium, 2010). The study was carried out in six states with 42 schools that were randomly assigned to receive the interventions versus continuing their regular programming. The programs were evaluated starting in third grade and continued through fifth grade. In total, over 6000 students were included in the evaluation. One of the programs focused more on character education, which is a strategy discussed below. Although all of the programs were found to implement their teaching objectives, the evaluation was essentially unable to identify consistent effects on the many outcomes said to comprise SEL outcomes during the period of the intervention. One of the interventions did begin to demonstrate effects after continued intervention into the seventh and eighth grades (Duncan et al., 2017).

It is clear that to reach the many goals of SEL, one needs a strategy for achieving them within the school context. As noted by Brunn (2014), " $t]$ he difficult thing for schools is not deciding whether or not to include social and emotional learning with the academic curriculum. The challenge is trying to figure out how to do it" (p. 265). Simply providing students with skills disconnected from the context in which they are practiced may not be sufficient to produce lasting change. 
We illustrate how schools can integrate SEL principles into the school curriculum by looking at two programs that successfully achieved this goal. These programs use a whole school approach in which teachers are trained to create a caring environment that increases attachment to the school and that fosters a cooperative and respectful climate. We now turn to programs that focus on creating a school climate that fosters the goals of PYD.

\section{School Climate}

Successful PYD programs in schools adopt a whole-school approach that integrates the goals of PYD into the academic program. This approach, like SEL, has many exemplars but also tends to be implemented at the elementary level. In this approach, the aim is to create a learning environment that is safe and respectful of student needs. Students are given a voice in how classes are structured and cooperation in group activities is encouraged. Two successful exemplars of this approach are the Seattle Social Development Project (SSSP) (Hawkins et al., 2001) and the Child Development Project (CDP) of the Developmental Studies Center (Battistich et al., 2004). Both programs adopt as the primary goal the establishment of a caring school climate that encourages bonding or attachment to the teachers and fellow students, an important form of connection. In these climates, students feel part of a community that is accepting and respectful of individuals. In the process, students adopt the norms and behaviours inculcated by teachers in their instructional styles (cf. LaRusso, Romer, \& Selman, 2007).

What distinguishes these programs is the careful integration of PYD goals into the curriculum such that students learn how to cooperate and show respect towards each other and towards teachers by engaging in activities that embody these goals. For example, in the CDP, "students work together in pairs or small groups on tasks that require collaboration and often have group products" (Solomon, Battistich, Watson, Schaps, \& Lewis, 2000, p. 6). In addition, "teachers discuss with students the values—such as fairness, consideration for others, responsibility - that underlie groupwork and the specific social skills and behavior from the values" (p. 7). They also learn decisionmaking skills as part of the academic program. This strategy is consistent with the Aristotelian approach of doing virtuous activity in order to develop virtuous capacities.

Evaluations of both programs have shown that attachment to school is a primary outcome from which other effects stem. In the case of the SSSP, school bonding was assessed with items reflecting liking for school. These effects lasted until the last years of high school indicating that early bonding 
experiences endured into later years of schooling. Remaining attached to school is an important outcome in its own right because it tends to enhance academic achievement and reduce unhealthy behaviours, such as drug use and early sexual activity, all of which were observed as a result of the SSSP (Hawkins et al., 2001). In the case of the CDP, measures of seeing the school as a community were stronger in intervention schools with an effect size of $r=.47$, and this outcome mediated a range of PYD outcomes, such as feeling a sense of heightened intrinsic academic motivation, with an effect size of $r=.33$.

These examples illustrate the potential for implementing PYD programs in elementary schools with lasting effects. Evidence for middle and high schools is less robust. However, there is evidence that schools that encourage respectful relations between students and teachers in a fair disciplinary structure promote enhanced academic outcomes even in grades 9 through 12 (e.g., Cornell, Shulka, \& Konold, 2016). There is also evidence that school climates that encourage respectful relations reduce adverse interpersonal events such as bullying (Voight $\&$ Nation, 2016). A meta-analysis across 51 studies mostly in the USA and Australia found that relationships with teachers play a large role in reports of school attachment at the high school level (Allen et al., 2018).

\section{Character Education}

The field of character education overlaps with SEL and other approaches to PYD, but according to Berkowitz and Bier (2014):

Character is the set of psychological characteristics that motivate and enable an individual to function as a competent moral agent. In other words, it is those aspects of one's psychological makeup that impact whether one does the right thing, whether that entails telling the truth, helping an unpopular student who is in jeopardy, resisting the temptation to cheat or steal, or some other matter of moral functioning. (p. 250)

This definition clearly places ethics at the centre of character education, a focus in line with the Aristotelian approach to happiness. Berkowitz sees character education as a subset of SEL, which we have already discussed. However, because SEL does not directly focus on ethics per se, this leaves the question of how best to inculcate the virtues into schooling unexplained. Indeed, Berkowitz and Bier in their latest review essentially sidestep this question. 
Another approach to character education is presented by Davidson, Lickona, and Khmelkov (2014), who encapsulate it as containing two goals, the development of performance and moral character. Performance character is the set of qualities or assets that enable one "to realize one's potential for excellence" (p. 293) such as developing an ethic of perseverance. Moral character is the set of virtues that enable one to treat others with respect and care. These two aspects of character are closely in line with Aristotelian approaches to self-fulfilment and happiness. They cite approaches that can be used in high schools to cultivate both sides of character, one of which is service learning, to which we turn below.

In a yet different approach, Narvez and Bock (2014) argued for the development of "moral expertise" much again in line with Aristotle: "applying the right virtue in the right amount in the right way at the right time" (p. 142). Their approach emphasizes the same principles that have been identified in the creation of supportive social climates in schools, such as establishing caring relationships with students and encouraging respect for peers as well as teachers in a cooperative learning environment. They also highlight the importance of developing a civic identity so that the student will be able to become a virtuous citizen. This form of PYD is advanced through civic education, which we also discuss below.

\section{Organized Youth Programs}

Early conceptions of PYD focused on the importance of youth programs available outside of the typical school day. These programs were seen as providing opportunities for youth to develop talents and become connected to their community. Advocates of this source of PYD noted that programs such as $4 \mathrm{H}$-Clubs, Boys and Girls Clubs, and scouting have long been promoted as avenues for PYD. During the early 2000s, scholars began to identify components of out-of-school programs that promote positive development (Catalano, Berglund, Ryan, Lonczak, \& Hawkins, 2004; Eccles \& Gootman, 2002; Lerner, 2004; Mahoney, Larson, Eccles, \& Lord, 2005). In 2005, the U.S. National Research Council and Institute of Medicine published a summary of the research on community programs that promote positive development (Eccles \& Gootman, 2002). In this publication, scholars identified eight features of positive developmental settings including: physical and psychological safety, appropriate structure, supportive relationships, opportunities to belong, positive social norms, support for efficacy, and mattering, opportunities for skill-building, and integration of family, 
school, and community efforts. These features embody PYD principles and have served to frame research on organized youth programs.

Participation and PYD. A recent analysis by Agans et al. (2014) from the Lerner longitudinal study of out-of-school participation in grades 7 through 12 identified the importance of sustained participation in such programs. They found that youth who reported greater overall participation in various out-of-school programs over the course of middle and high school experienced greater levels of PYD as measured by the 5Cs. Not surprisingly, sports programs were the most popular activity, but religious programs were also quite popular, especially among youth who participated in multiple programs. These youth also tended to experience less depression and lower levels of risk behaviour, although this was not consistently true across the entire age span. In addition, two Cs were most important as outcomes of PYD, connection, and competencies, again reflecting what has been found in the SEL approach and what is emphasized by Deci and Ryan as important components of intrinsic motivation.

PYD and developmental experiences. Hansen and Larson conceptualized and developed a PYD research agenda around youth developmental experiences (e.g., goal setting, prosocial norms) in organized youth programs (Hansen, Larson, \& Dworkin, 2003; Hansen, Moore, \& Jessop, 2018; Hansen, Skorupski, \& Arrington, 2010; Larson \& Hansen, 2005; Larson, Hansen, \& Moneta, 2006; Larson, Hansen, \& Walker, 2005; Larson, Lampkins-Uthando, \& Armstrong, 2014). An example of a specific developmental experience resulting from youth programs is related to identity: This activity got me thinking about who I am (Hansen \& Larson, 2002). Theoretically, these developmental experiences form the basis for learning positive skills and competencies, although there is not yet research explicitly linking specific experiences to relevant skills.

In a study with a representative sample of 2280 11th grade students, Larson et al. (2006) examined profiles of developmental experiences across a wide range of out-of-school programs in which students participated. Results indicated that different types of youth programs, such as sports and arts, demonstrated distinct profiles of experiences. For example, compared to other youth programs, faith-based programs were associated with higher rates of identity, initiative, emotion regulation, teamwork and social skills, positive relationship, and adult network and social capital experiences. By way of comparison, sports were associated with higher rates of initiative, emotion regulation, and teamwork experiences but lower rates of identity, positive relationships, and adult network experiences. It is important to note that comparisons of developmental experiences between youth programs 
and English and Math classes indicated that youth programs were rated considerably higher on all developmental experiences.

Using a subsample of the representative sample in Larson et al. (2006), Hansen and Larson (2007) examined the association between developmental experiences and four program involvement indicators: "dosage" (hours per week), motivations for participating in the program, holding a lead role, and the ratio of adults-to-youth in the program. Results indicated that each of the indicators was independently associated with PYD developmental experiences, accounting for a total of $23 \%$ of the variance in experiences.

Overall, research on adolescents' developmental experiences suggests organized youth activities are a beneficial context for PYD. What this line of research does not yet address is the impact, both immediate and long term, of positive experiences on skill development. In addition, the measure of developmental experiences, the Youth Experience Survey (YES), was developed specifically to reflect the youth program setting. Thus, how well these experiences capture PYD experiences in other settings is unknown.

Program characteristics that promote PYD. Meta-analyses of the effects of extracurricular programs have produced mixed results. This is likely due to the great heterogeneity in program goals and strategies for attaining them. Durlak, Weissberg, and Pachan (2010) examined a wide range of programs mostly in the USA and found that the programs that followed what they called SAFE implementation were the most successful in achieving favourable outcomes. These programs had practices that were sequenced, active, focused, and explicit. In short, they used strategies that employed a structured set of goals that helped youth to build social and personal skills as described in their program manual and used active rather than merely didactic teaching styles that were focused on specific learning goals. They identified 41 SAFE programs out of 68 that had been studied. Most of the programs were designed for local elementary and middle school students rather than being part of large national organizations such as the 4-H or Boys and Girls clubs.

Durlak et al. (2010) looked at several outcomes, such as self-perceptions (e.g., self-esteem and self-efficacy) as well as bonding to school and school achievement as important effects. They found that the SAFE programs produced effects in the range of $r=.14$ (for school attendance) to $r=.37$ (for self-perceptions). However, the effects for the other programs were largely negligible. Thus, their review suggested that appropriately designed programs could produce favourable outcomes.

Despite the favourable review by Durlak et al. (2010), a Campbell systematic review of out-of-school programs found limited effects on academic or 
behavioural outcomes (Zief, Lauver, \& Maynard, 2006). The lack of consistent effects led Ciocanel, Power, Eriksen, and Gillings (2017) to conduct another evaluation of organized youth programs. They attempted to identify all randomized trials in both the published and unpublished literature and to use established criteria for program quality. With these criteria, they identified 24 programs, 20 of which were conducted in the U.S. The average ages ranged from 10 to 16 at baseline.

Ciocanel et al. (2017) examined three classes of outcomes: academic including grades in school, self-perceptions of efficacy and esteem, and prosocial and problem behaviour. There were small effects on academic achievement with an effect size of $r=.22$. There were also effects on selfperceptions with a size of $r=.19$. No effects on social or problem behaviour were observed. The authors also noted heterogeneity in effects that seemed to be stronger for lower risk youth.

The authors of this evaluation were less enthusiastic about the current state of out-of-school programs. However, the programs that were included in the review seemed to focus on problem behaviour and school performance, without much attention to the 5C's or contribution.

Youth-adult partnerships. This strand of research has focused on the role of adults in partnering with young people as a means of advancing PYD (Ramey \& Rose-Krasnor, 2012; Sullivan \& Larson, 2010; Zeldin, 2000), and has examined the effects that youth have on adults as they attempt to enter into cooperation with adults in the community. It also recognizes the negative stereotypes that adults hold of youth that hinder their willingness to include young people's voice in their programs. Reviews of characteristics of out-of-school activities that appear to make them successful use interviews with both youth and adults. These studies generally find that youth programs are most successful "when youth felt respected, were able to contribute, and played meaningful roles that drew on their strengths" (Sullivan \& Larson, 2010; p. 101).

In summary, there is considerable room for refinement of out-of-school programs. Although the Durlak et al. (2010) review identified successful programs, the content of those programs remains obscure other than that they employed SAFE strategies (see also Roth \& Brooks-Gunn, 2016, for similar concerns). Agans et al. (2014) study did not involve random assignment, so it is not clear whether the youth who participated in more programs were just more capable of exhibiting PYD. The same can be said about the findings of Scales et al. (2000). On the other hand, even if out-of-school programs largely reflect selection effects, it is reassuring to know that they are associated with more favourable PYD outcomes given their widespread availability 
in many locales. The challenge is to identify the program characteristics that can lead to stronger outcomes relevant to the PYD agenda, such as personal assets or the 5 Cs.

\section{Civics Education}

Development of civic virtues is clearly relevant to the PYD agenda, since it is designed to encourage participation in community decision-making. As noted above, it is often cited as an objective of character education (Berkowitz, Althof, \& Jones, 2008; Narvez \& Bock, 2014). However, interest in civics as an educational objective predates the emergence of the PYD approach to healthy development. Studies of the effects of civic education go back to at least 1967 in the studies of Hess and Torney (1967). One stream of this research concerns the basic function of civics education, namely the acquisition of knowledge about one's government and regulations regarding participation in it, including voting (e.g., Niemi \& Junn, 1998). Indeed, considerable evidence supports the importance of civics knowledge as a marker of active citizenship, such as voting (Delli Carpini \& Keeter, 1996). It would be expected that exposure to civics classes in schools would lead to greater knowledge about it and hence to civic outcomes such as voting. But the correlation between taking civics classes and knowledge is small (Niemi $\&$ Junn, 1998). And the relation between civics knowledge and actual political participation in young people is also tenuous (Pasek, Feldman, Romer, \& Hall Jamieson, 2008; Reichert, 2016).

Since the ground-breaking work of Hess and Torney (1967) and because of its obvious relevance to the socialization of good citizens, the International Association for the Evaluation of Educational Achievement (IEA) has conducted four international studies of civic education since 1971. These studies have focused on children in the eighth grade (ages 14-15) from multiple countries. The surveys have also included teachers and administrators. The strongest conclusion from these studies that "consistently emerged across countries, contexts, times and groups... was that an open, participatory and respectful discussion climate is associated with civic knowledge and engagement" (Knowles, Torney-Purta, \& Barber, 2018, p. 13). Students who report such civics classes endorse items indicating that they are encouraged to freely express their opinions and make up their own minds about political issues. There has also been evidence that effects of class climate are stronger for students from less advantaged backgrounds (Campbell, 2007).

Attention has also been directed to characteristics of teachers who are more likely to produce favourable outcomes. A variety of teaching techniques have 
been associated with these outcomes, with no single one being any stronger than another as long as a climate of respectful discussion was maintained. Nevertheless, teachers tend to be more confident discussing some topics than others. For example, in the U.S., teachers reported feeling unease discussing controversial topics (Alviar-Martin et al., 2008). Another study found that "teachers who personally felt strongly about environmental and human rights issues were more likely to endorse an open classroom climate than were teachers who felt strongly about the importance of conforming to the law" (Knowles et al., 2018, p. 15). Those who were more comfortable raising controversial issues had students with greater civic knowledge.

An important outcome of civics education that has emerged in recent years is a sense of internal efficacy (Knowles \& McCafferty-Wright, 2015; Manganelli, Lucidi, \& Alivernini, 2015; Pasek et al., 2008; Reichert, 2016). Two types of internal efficacy have been identified: civic efficacy and political efficacy. Civic efficacy concerns the more general perceived ability to discuss and debate about issues of concern to the community; while political efficacy is more focused on the ability to participate in and potentially have a voice in politics through voting and discussion. Both have been associated with civic education that encourages learning about political issues in the media and developing an understanding of the arguments for and against particular positions. In one IEA study across 13 European countries (Knowles \& McCafferty-Wright, 2015), the relation between both types of efficacy and perceptions of open classes was quite strong. Further, both types of efficacy as well as civic knowledge were found to mediate the relation between open classes and the reported importance of participation in civic and political life, a result that characterized all 13 countries. Similar relations have been found in other studies (Pasek et al., 2008; Reichert, 2016), with evidence that the relation holds at both the classroom and individual level (Manganelli et al., 2015).

A somewhat pessimistic evaluation of civics education was reached by Manning and Edwards (2014). They identified nine studies that compared a civics curriculum for youth against a control condition with a focus on a behavioural outcome, such as voting or signing a petition. However, no studies using random assignment were identified. They concluded that the evidence in favour of direct effects of the programs on voting was either lacking or of uncertain statistical significance. They did find evidence of effects on other forms of political expression, such as signing petitions and contacting a government official. In some cases, the effects on voting were mediated by such variables as political efficacy (e.g., Pasek et al., 2008), which the authors discounted. In total, their review showed that the research 
testing the direct effects of civics education failed to use the best types of research design and that this inevitably limited the conclusions that could be drawn. Unfortunately, they did not assess the degree to which the programs employed the features of open discussion that have been identified as critical to the success of civics education. Thus, their pessimism seems unwarranted given the evidence of positive effects in most of the studies reviewed.

Evidence has also accumulated in the IEA studies regarding participation in school activities, such as student councils and other activities that encourage student voice in the school's administration (Mager \& Nowak, 2012). Although some effects were stronger than others, all forms of participation appeared to improve the school's climate as evidenced by greater attachment to and enjoyment of school.

It is often lamented that civics education has received short-shrift in the U.S. (Shapiro \& Brown, 2018). Nevertheless, it is encouraging that voting and political participation have recently increased among American young people (Clement \& Mellnik, 2019). It is also noteworthy that adolescents have been at the forefront of some social movements, such as greater regulation of guns and more concerted effort to combat climate change. If these trends continue, it would suggest that young people are becoming more civically and politically engaged than in the past despite the weak status of civic education in the schools.

\section{Service Learning}

As noted in the review of approaches to character education, perhaps the most common strategy to develop a moral sense in education is the use of community service and its curricular embodiment of service learning. Although this approach differs from the traditional form of civics education, which focuses on knowledge about the workings of government and, when successful, open discussion about political issues, civics education and service learning are often contrasted as strategies for developing what might be called civic virtues (e.g., Hart, Donnelly, Youniss, \& Atkins, 2007).

Service learning is said to have its roots in John Dewey's Democracy and Education (1961) which advocated for the importance of the school curriculum in the development of socially concerned citizens. He also advocated for a "learning by doing" curriculum, which is consistent with an Aristotelian approach to ethical development. By engaging in service projects, youth are expected to develop an appreciation of the social and economic problems in their communities and the ways in which they can contribute to their solution (Hart et al., 2014). In addition, by actively reflecting on 
their experience, students are thought to gain greater understanding and appreciation of their experience.

Some forms of community service have been studied even when they are not linked to a formal curriculum. These activities merely involve participation in a service activity in the community. In a random sample of 18,000 U.S. students in eighth grade in 1988 at baseline, Hart et al. (2007) examined the relation between both voluntary and required service activity during school years and engagement in various civic outcomes eight years after graduation. At a follow-up with over 6,000 respondents, a little over a fifth of the former students had volunteered in their community in the past 12 months. Larger proportions (46-62\%) had voted in a recent election. With controls for a variety of personal and demographic factors, the results indicated strong associations between having engaged in either voluntary or required service during high school and voting at follow-up.

Hart et al. (2007) study also found that although civic knowledge as assessed at 12th grade was related to the number of social science classes taken, it was only related to voting at follow-up. Hart et al. (2007) summarized their findings "that providing opportunities for community service and extracurricular activities are particularly good choices for policy makers interested in grooming adolescents for citizenship" (p. 216).

Other studies have identified some of the factors that may mediate the effects of service learning. In one review of service learning, students in the programs were observed to be more adept at taking different perspectives in moral reasoning (Conrad \& Hedin, 1982). Another study by Scales, Blyth, Berkas, and Kielsmeier (2000) with over one thousand middle school students found that participation in service-learning programs led to greater efficacy beliefs about their ability to help others and stronger concern for others' welfare compared to students not in such programs. These effects were stronger the longer the exposure to the programs and when the programs involved reflection exercises that reviewed the service experience.

Conway et al. (2009) conducted a meta-analysis of 78 studies comparing service learning to control conditions. The studies focused on the entire range of education, from elementary to college students. The analysis found effects on citizenship as well as personal and social outcomes. The largest effects were found for academic outcomes $(d=.43)$, such as grades. The smallest effects were associated with citizenship outcomes $(d=.17)$, such as frequency of volunteering for service. The effect was somewhat stronger when the program included time for reflection $(d=.22)$. The effects of service-learning were observed at all levels of education. Another meta-analysis of service-learning programs with 62 studies found effects in the same range (Celio et al., 2011). 
Not unlike other PYD programs, there is limited evidence about the components of service learning that produce the most effect on civic outcomes. Many have argued that reflection is critical, but this has not been established to date. The large study by Hart et al. (2007) suggests that even voluntary community service without a direct connection to course requirements can lead to greater civic and political outcomes. Furthermore, the content of reflection activities that might be effective has not been clearly isolated. Some involve writing journals while others just encourage discussion. The type of service activity has also not been clearly identified. Youniss and colleagues (Metz et al., 2003) have suggested that service involving direct contact with people in need should be more impactful than less direct contact. Further research will be needed to identify the best practices in this area of PYD education (Hart et al., 2014).

\section{Conclusions and Challenges for the Future}

PYD is an active and promising approach to the healthy development of youth. It provides a conceptual umbrella for youth of all ages and in all contexts. Although much remains to be understood about the best ways to implement PYD programs, one conclusion that emerges from this review is the importance of classroom and school climates as critical for the positive development of youth. Consistent with John Dewey's argument, to develop virtuous citizens in a democracy will require democratic practices in and outside of schools (Dewey, 1961). These include an open and inclusive climate that encourages youth to learn in a setting of respect and cooperation whether they be with fellow students, teachers, or other adults in the community. This learning by doing increases connection to the setting and the adults who lead it. When teachers and adults in community programs approach education as a cooperative endeavour between adults and students and between students themselves, they are more likely to produce PYD outcomes. The strategies to accomplish this depend on the cognitive development of youth, but sufficient evidence has accumulated that PYD programs with these characteristics can further the various Cs at all ages.

Several challenges remain for PYD to reach its full potential. First, although PYD as practice, theory, and research has considerable potential to inform education, applying a PYD framework to education will challenge the traditional teacher-student model. Learning within the PYD framework is principled on the person and the community dynamically exerting a bidirectional influence (Lerner, 1998). The degree of influence and the direction 
of influence in teacher-student relationship can have a profound impact on learning. The teacher-student relationship has traditionally been unidirectional in the sense that the teacher determined what was learned. A PYD framework challenges this conceptualization. Although schools are apt to see themselves as a "community" delivery system for PYD, formal education struggles to adhere to the core PYD tenet of the individual as an active agent who can direct their own learning goals. What teacher-student relationships in a PYD model means for formal education is, admittedly, difficult to envision but a necessary task. These challenges will continue to occupy both practitioners and researchers in the years to come.

Second, age matters. Despite sharing common tenets, there are important developmental differences between childhood and adolescence that should inform formal educational adaptations of PYD practice and theory. While age is an important consideration in PYD practice and theory, PYD applications have had the most traction in elementary education, most often in the form of SEL curricula. We suggest the traction PYD has had in elementary education again reflects embedded structural limitations of a prescriptive formal educational system that is ill-suited at present to accommodating adolescent agency-driven development.

Finally, there has been less attention to the implementation of PYD programs within resource-limited settings and for youth living in household poverty. The Lerner study of $4 \mathrm{H}$ clubs found that youth living in poverty were less able to display growth in the Cs than more advantaged youth (Phelps et al., 2007). Given the high rates of youth poverty in many countries including the U.S., it will continue to be a challenge to implement successful PYD programs for less advantaged youth.

\section{References}

Agans, J. P., Champine, R. B., DeSouza, L. M., Mueller, M. K., Johnson, S. K., \& Lerner, R. M. (2014). Activity involvement as an ecological asset: Profiles of participation and youth outcomes. Journal of Youth and Adolescence, 43, 919-932. https://doi.org/10.1007/s10964-014-0091-1.

Allen, K., Kern, M. L., Vella-Brodrisk, D., Hattie, J., \& Waters, L. (2018). Waht schools need to know about fostering school belonging: A meta-analysis. Educational Psychological Review, 30, 1-34. https://doi.org/10.1007/s10648-0169389-8.

Alviar-Martin, T., Randall, J., Usher, E., \& Englehard, G. (2008). Teaching civic topics in four societies: Examining national context and teacher confidence. Journal of Educational Research, 101(3), 177-188. 
Battistich, V., Schaps, E., \& Wilson, N. (2004). Effects of an elementary school intervention on students' "connectedness" to school and social adjustment during middle school. The Journal of Primary Prevention, 42(3), 243-262.

Benson, P. L., Scales, P. C., Hamilton, S. F. and Sesma, A., Jr. (2007). Positive youth development: Theory, research, and applications. In W. Damon, R. M. Lerner, \& R.M. Lerner (Eds.), Handbook of Child Psychology. https://doi.org/10.1002/ 9780470147658.chpsy0116.

Berkowitz, M. W., Althof, W., \& Jones, S. (2008). Educating for civic character. In J. Arthur, I. Davies, \& C. Hahn (Eds.), The Sage handbook of education for citizenship and democracy (pp. 399-409). Sage.

Berkowitz, M. W., \& Bier, M. C. (2014). Research-based fundamentals of the effective promotion of character development in schools. In Handbook of moral and character education (2nd ed., pp. 248-260). Routledge.

Brunn, P. (2014). Pedagogy for the whole child: The developmental studies center's approach to academic, moral, and character development. In L. Nucci, D. Narvez, \& T. Krettenauer (Eds.), Handbook of moral and character education (2nd ed., pp. 263-271). Routledge.

Campbell, D. E. (2007). Sticking together: Classroom diversity and civic education. American Politics Research, 35(1), 57-78.

Catalano, R. F., Berglund, M. L., Ryan, J. A., Lonczak, H. S., \& Hawkins, J. D. (2004). Positive youth development in the United States: Research findings on evaluations of positive youth development programs. The Annals of the American Academy of Political and Social Science, 591(1), 98-124.

Celio, C. I., Durlak, J. A., \& Dymnicki, A. B. (2011). A meta-analysis of the impact of service-learning on students. Journal of Experiential Education, 34(2), 164-181.

Ciocanel, O., Power, K., Eriksen, A., \& Gillings, K. (2017). Effectiveness of positive youth development interventions: A meta-analysis of randomized controlled trials. Journal of Youth and Adolescence, 46, 483-504. https://doi.org/10.1007/s10 964-016-0555-6.

Clement, S., \& Mellnik, T. (2019, April 23). Young people actually rocked the vote in 2018, new Census Bureau data finds. The Washington Post. https://www.washingtonpost.com/politics/2019/04/23/young-peo ple-actually-rocked-vote-new-census-data-find/.

Conrad, D., \& Hedin, D. (1982). The impact of experiential education on adolescent development. Child \& Youth Services, 4, 57-76.

Conway, J., Amel, E. L., \& Gerwien, D. P. (2009). Teaching and learning in the social context: A meta-analysis of service learning's effects on academic, personal, social, and citizenship outcomes. Teaching of Psychology, 36, 233-245. https://doi. org/10.1080/00986280903172969.

Conway, R. J., Heary, C., \& Hogan, M. J. (2015). An evaluation of the measurement properties of the five Cs model of positive youth development. Frontiers in Psychology, 6(1941), 1-13. https://doi.org/10.3389/fpsyg.2015.01941. 
Cornell, D., Shulka, K., \& Konold, T. R. (2016). Authoritative school climate and student academic engagement, grades, and aspirations in middle schools. AERA Open, 2(2), 1-18. https://doi.org/10.1177/2332858416633184.

Cubberley, E. P. (1919). Public education in the United States: A study and interpretation of American educational history. Houghton Mifflin Company. https://arc hive.org/details/publiceducationi00cubbuoft/page/n4.

Davidson, M., Lickona, T., \& Khmelkov, V. (2014). Smart \& good schools: A new paradigm for high school character education. In L. Nucci, D. Narvez, \& T. Krettenauer (Eds.), Handbook of moral and character education (2nd ed., pp. 290 305). Routledge.

Delli Carpini, M. X., \& Keeter, S. (1996). What Americans know about politics and why it matters. New Haven, CT: Yale University Press.

Dewey, J. (1961). Democracy and education: An introduction to the philosophy of education. Macmillan.

Diener, E., Lucas, R. E., \& Scollon, C. N. (2006). Beyond the hedonic treadmill: Revising the adaptation theory of well-being. American Psychologist, 61(4), 305314. https://doi.org/10.1037/0003-066X.61.4.305.

Duerden, M. D., Widmer, M. A., \& Witt, P. A. (2017). Positive youth development: What it is and how it fits in therapeutic settings. Journal of Therapeutic Schools and Programs, 4(1), 1698.

Duncan, R., Washburn, I. J., Lewis, K. M., Bavarian, N., Dubois, D. L., Acock, A. C., et al. (2017). Can universal SEL programs benefit universally? Effects of the positive action program on multiple trajectories of social-emotional and misconduct behaviors. Prevention Science, 18, 214-224. https://doi.org/10.1007/ s11121-016-0745-1.

Durlak, J. A., Weissberg, R. P., Dymnicki, A. B., Taylor, R. D., \& Schellinger, K. B. (2011). The impact of enhancing students' social and emotional learning: A meta-analysis. Child Development, 82, 405-432. https://doi.org/10.1111/j.14678624.2010.01564.x.

Durlak, J. A., Weissberg, R. P., \& Pachan, M. (2010). A meta-analysis of afterschool programs that seek to promote personal and social skills in children and adolescents. American Journal of Community Psychology, 45, 294-309. https://doi. org/10.1007/s10464-010-9300-6.

Eccles, J., \& Gootman, J. A. (2002). Community programs to promote youth development. National Academies Press.

Forgeard, M. J. C., Jayawickreme, E., Kern, M. L., \& Seligman, M. E. P. (2011). Doing the right thing: Measuring wellbeing for public policy. International Journal of Wellbeing, 1(1), 79-106. https://doi.org/10.5502/ijw.v1i1.15.

Geldhof, G. J., Bowers, E. P., Mueller, M. K., Napolitano, C. M., Callina, K. S., \& Lerner, R. M. (2014). Longitudinal analysis of a very short measure of positive youth development. Journal of Youth and Adolescence, 43, 933-949. https://doi. org/10.1007/s10964-014-0093-z.

Hansen, D. M., \& Larson, R. (2002). The youth experience survey. Unpublished manuscript, University of Illinois at Urbana-Champaign. 
Hansen, D. M., \& Larson, R. W. (2007). Amplifiers of developmental and negative experiences in organized activities: Dosage, motivation, lead roles, and adultyouth ratios. Journal of Applied Developmental Psychology, 28(4), 360-374.

Hansen, D. M., Larson, R. W., \& Dworkin, J. B. (2003). What adolescents learn in organized youth activities: A survey of self-reported developmental experiences. Journal of Research on Adolescence, 13(1), 25-55.

Hansen, D. M., Moore, E. W., \& Jessop, N. (2018). Youth program adult leader's directive assistance and autonomy support and development of adolescents' agency capacity. Journal of Research on Adolescence, 28(2), 505-519.

Hansen, D. M., Skorupski, W. P., \& Arrington, T. L. (2010). Differences in developmental experiences for commonly used categories of organized youth activities. Journal of Applied Developmental Psychology, 31(6), 413-421.

Hart, D., Donnelly, T. M., Youniss, J., \& Atkins, R. (2007). High school community service as a predictor of adult voting and volunteering. American Educational Research Journal, 44(1), 197-219. https://doi.org/10.3102/0002831206298173.

Hart, D., Matsuba, M. K., \& Atkins, R. (2014). The moral and civic effects of learning to serve. In L. Nucci, D. Narvez, \& T. Krettenauer (Eds.), Handbook of moral and character education (2nd ed., pp. 456-470). Routledge.

Hawkins, J. D., Guo, J., Hill, K. G., Battin-Pearson, S., \& Abbott, R. (2001). Longterm effects of the Seattle Social Development Intervention on school bonding trajectories. Applied Developmental Science, 5(4), 225-236.

Hess, V. K., \& Torney, J. V. (1967). The development of political socialization. Aldine. Jebb, A. T., Morrison, M., Tay, L., \& Diener, E. (2020). Subjective well-being around the world: Trends and predictors across the life span. Psychological Science. https://doi.org/10.1177/0956797619898826.

Jones, S. M., Barnes, S. P., Bailey, R., \& Doolittle, E. J. (2017). Promoting social and emotional competencies in elementary school. The Future of Children, 27(1), 49-72.

Kashdan, T. B., Biswas-Diener, R., \& King, L. A. (2008). Reconsidering happiness: The costs of distinguishing between hedonics and eudaimonia. Journal of Positive Psychology, 3(4), 219-233. https://doi.org/10.1080/17439760802303044.

Kern, M. L., Park, N., \& Romer, D. (2017). The positive perspective on youth development. In D. L. Evans, E. B. Foa, R. E. Gur, H. Hendin, C. P. O’Brien, D. Romer, M. E. P. Seligman, \& B. T. Walsh (Eds.), Treating and preventing adolescent mental health disorders: What we know and what we don't know (2nd ed., pp. 1-28). Oxford University Press. https://doi.org/10.1093/med-paych/978 0199928163.001 .0001$.

Keyes, C. L. M. (2007). Promoting and protecting mental health as flourishing: A complementary strategy for improving national mental health. American Psychologist, 62(2), 95-108. https://doi.org/10.1037/0003-066X.62.2.95.

Klaczynski, P. A. (2005). Metacognition and cognitive variability: A dual-process model of decision making and its development. In The development of judgment and decision making in children and adolescents (pp. 39-76). Mahwah, 
NJ, US: Lawrence Erlbaum Associates Publishers. https://doi.org/10.1037/0003066X.62.2.95.

Knowles, R. T., \& McCafferty-Wright, J. (2015). Connecting an open classroom climate to social movement citizenship: A study of 8th graders in Europe using IEA ICCS data. The Journal of Social Studies Research, 39, 255-269.

Knowles, R. T., Torney-Purta, J., \& Barber, C. (2018). Enhancing citizenship learning with international comparative research: Analyses of IEA civic education datasets. Citizenship Teaching \& Learning, 13(1), 7-30. https://doi.org/10. 1386/ctl.13.1.7_1.

Larson, R. W. (2000). Toward a psychology of positive youth development. American Psychologist, 55(1), 170.

Larson, R., \& Hansen, D. (2005). The development of strategic thinking: Learning to impact human systems in a youth activism program. Human Development, 48(6), 327-349.

Larson, R. W., Hansen, D. M., \& Moneta, G. (2006). Differing profiles of developmental experiences across types of organized youth activities. Developmental Psychology, 42(5), 849-863.

Larson, R., Hansen, D., \& Walker, K. (2005). Everybody's gotta give: Development of initiative and teamwork within a youth program. In J. L. Mahoney, J. S. Eccles, \& R. W. Larson (Eds.), Organized activities as contexts of development: Extracurricular activities, after-school and community programs (pp. 159-183). Mahwah, NJ: Lawrence Erlbaum.

Larson, R. W., Lampkins-Uthando, S., \& Armstrong, J. (2014). Adolescents' development of new skills for prospective cognition: Learning to anticipate, plan, and think strategically. Journal of Cognitive Education and Psychology, 13(2), 232-244.

LaRusso, M. D., Romer, D., \& Selman, R. L. (2007). Teachers as builders of respectful school climates: Implications for adolescent drug use norms and depressive symptoms in high school. Journal of Youth and Adolescence, 37, 386-398.

Lefferts, N., Benson, P. L., Scales, P. C., Sharma, A. R., Drake, D. R., \& Blyth, D. A. (1998). Developmental assets: Measurement and prediction of risk behaviors among adolescents. Applied Developmental Science, 2(4), 209-230.

Lerner, R. M. (1998). Theories of human development: Contemporary perspectives. In W. Damon \& R. M. Lerner (Eds.), Handbook of child psychology: Theoretical models of human development (p. 1-24). John Wiley \& Sons Inc.

Lerner, R. M. (2004). Liberty: Thriving and civic engagement among America's youth. Sage.

Lerner, R. M., Fisher, C. B., \& Weinberg, R. A. (2000). Toward a science for and of the people: Promoting civil society through the application of developmental science. Child Development, 71(1), 11-20.

Lerner, R. M., Theokas, C., \& Jelicic, H. (2005). Youth as active agents in their own positive development: A developmental systems perspective. In W. Greve, K. Rothermund, \& D. Wentura (Eds.), The adaptive self: Personal continuity and intentional self-development (pp. 31-47). Hogrefe \& Huber Publishers. 
Lerner, R. M., Lerner, J. V., Geldhof, G. J., Gestsdóttir, S., King, P. E., Sim, A. T., ... Dowling, E. (2018). Studying positive youth development in different nations. In Handbook of adolescent development research and its impact on global policy (pp. 68-83). New York: Oxford University Press.

Lewin-Bizan, S., Lynch, A. D., Fay, K., Schmid, K., McPherran, C., Lerner, J. V., et al. (2010). Trajectories of positive and negative behaviors from early- to middle-adolescence. Journal of Youth and Adolescence, 39, 751-763. https://doi. org/10.1007/s10964-010-9532-7.

Mager, U., \& Nowak, P. (2012). Effects of student participation in decision making at school. A systematic review and synthesis of empirical research. Educational Research Review, 7, 38-61.

Mahoney, J., Larson, R., Eccles, J., \& Lord, H. (2005). Organized activities as developmental contexts for children and adolescents. In J. L. Mahoney, J. S. Eccles, \& R. W. Larson (Eds.), Organized activities as contexts of development: Extracurricular activities, after-school and community programs (pp. 3-22). Mahwah, NJ: Lawrence Erlbaum.

Manganelli, S., Lucidi, F., \& Alivernini, F. (2015). Italian adolescents' civic engagement and open classroom climate: The mediating role of self-efficacy. Journal of Applied Developmental Psychology, 41, 8-18.

Manning, N., \& Edwards, K. (2014). Does civic education for young people increase political participation? A Systematic Review. Educational Review, 66 (1), 22-45. https://doi.org/10.1080/00131911.2013.763767.

Metz, E., McLellan, J., \& Youniss, J. (2003). Types of voluntary service and adolescents' civic development. Journal of Adolescent Research, 18, 188-203.

Narvez, D., \& Bock, T. (2014). Developing ethical expertise and moral personalities. In L. Nucci, D. Narvez, \& T. Krettenauer (Eds.), Handbook of moral and character education (2nd ed., pp. 140-158). Routledge.

Niemi, R. G., \& Junn, J. (1998). Civic education: What makes students learn. New Haven, CT: Yale University Press.

Pasek, J., Feldman, L., Romer, D., \& Hall Jamieson, K. (2008). Schools as incubators of democratic participation: Building long-term political efficacy with civic education. Applied Developmental Science, 12(1), 26-37. https://doi.org/10.1080/ 10888690801910526.

Peterson, C., \& Seligman, M. E. P. (2004). Character strengths and virtues: A classification and handbook. American Psychological Association.

Phelps, E., Balsano, A., Fay, K., Peltz, J., Zimmerman, S., \& Lerner, R. M. (2007). Nuances in early adolescent developmental trajectories of positive and problematic/risk behaviors: Findings from the $4 \mathrm{H}$ study of positive youth development. Child and Adolescent Psychiatric Clinics of North America, 16, 473-496.

Pittman, K., \& Fleming, W. (1991). A new vision: Promoting youth development. Testimony of Karen Johnson Pittman Vice President Academy for educational development director center for youth development and policy research before the house select committee on children youth and families. 
Pittman, K., Irby, M., \& Ferber, T. (2000). Unfinished business: Further reflections on a decade of promoting youth development (pp. 17-64). Public/Private Ventures. https://www.issuelab.org/resources/12137/12137.pdf.

Qu, L., \& de Vaus, D. (2015). Life satisfaction across life course transitions (Australian Family Trends, No. 8; p. 14). Australian Institute of Family Studies.

Ramey, H. L., \& Rose-Krasnor, L. (2012). Contexts of structured youth activities and positive youth development. Child Development Perspectives, 6(1), 85-91. https://doi.org/10.1111/j.1750-8606.2011.00219x.

Reichert, F. (2016). How internal political efficacy translates political knowledge into political participation. European Journal of Psychology, 12(2), 221-241. https://doi.org/10.5964/ejop.v12i2.1095.

Roth, J. L., \& Brooks-Gunn, J. (2003). What exactly is a youth development program? Answers from research and practice. Applied Developmental Science, 7(2), 94-111.

Roth, J. L., \& Brooks-Gunn, J. (2016). Evaluating youth developmental programs: Progress and promise. Applied Developmental Science, 20(3), 188-202. https:// doi.org/10.1080/10888691.2015.1113879.

Ryan, R. M., \& Deci, E. L. (2000). Self-determination theory and the facilitation of intrinsic motivation, social development, and well-being. American Psychologist, 55(1), 68-78. https://doi.org/10.1037//0003-066X.55.1.68.

Ryan, R. M., \& Deci, E. L. (2001). On happiness and human potentials: A review of research on hedonic and eudaimonic well-being. Annual Review of Psychology, $52,141-166$.

Ryff, C. D. (1989). Happiness is everything, or is it? Explorations on the meaning of psychological well-being. Journal of Personality and Social Psychology, 57(6), 1069-1081.

Scales, P. C., Benson, P. L., \& Lefferts, N. (2000). Contribution of developmental assets to the prediction of thriving among adolescents. Applied Developmental Science, 4(1), 27-46.

Scales, P. C., Benson, P. L., Oesterle, S., Hill, K. G., Hawkins, J. D., \& Pashak, T. J. (2016). The dimensions of successful young adult development: A conceptual and measurement framework. Applied Developmental Science, 20(3), 150-174. https://doi.org/10.1080/10888691.2015.1082429.

Scales, P. C., Blyth, D. A., Berkas, T. H., \& Kielsmeier, J. C. (2000). The effects of service-learning on middle school students' social responsibility and academic success. Journal of Early Adolescence, 20(3), 332-358.

Seligman, M. E. P., \& Csikszentmihalyi, M. (2000). Positive psychology: An introduction. American Psychologist, 55, 5-14.

Shapiro, S., \& Brown, C. (2018). The state of civics education. Center for American Progress. www.americanprogress.org/issues/education-k-12/reports/2018/02/21/ 446857/state-civics-education/.

Sherman, N. (1991). The fabric of character: Aristotle's theory of virtue. Oxford: Oxford University Press. 
Shogren, K. A., \& Little, T. D. (2017). Human agentic theories and the development of self-determination. In M. L. Wehmeyer, K. A. Shogren, T. D. Little, \& S. J. Lopez (Eds.), Development of self-determination through the life-course (pp. 17-26). Springer.

Shure, M. (2001). I can problem solve: An interpersonal cognitive problem solving program for children (2nd ed.). Research Press.

Shure, M. (2003). A problem-solving approach to preventing early high-risk behaviors in children and pre-teens. In D. Romer (Ed.), Reducing adolescent risk: Toward an integrated approach (pp. 85-92). Sage.

Shure, M., \& Spivack, G. (1982). Interpersonal problem solving in young children: A cognitive approach to prevention. American Journal of Community Psychology, 10(3), 341-356.

Social and Character Development Research Consortium. (2010). Efficacy of schoolwide programs to promote social and character development and reduce problem behavior in elementary school children (NCER 2011-2001). National Center for Educational Research, Institute of Education Sciences, U.S. Department of Education.

Solomon, D., Battistich, V., Watson, M., Schaps, E., \& Lewis, C. (2000). A sixdistrict study of educational change: Direct and mediated effects of the child development project. Social Psychology of Education, 4, 3-51.

Steger, M. F., Oishi, S., \& Kashdan, T. B. (2009). Meaning of life across the life span: Levels and correlates of meaning in life from emerging adulthood to older adulthood. The Journal of Positive Psychology, 4(1), 43-52.

Sullivan, P. J., \& Larson, R. W. (2010). Connecting youth to high-resource adults: Lessons from effective youth programs. Journal of Adolescent Research, 25(1), 99123. https://doi.org/10.1177/07435588409350505.

Voight, A., \& Nation, M. (2016). Practices for improving secondary school climate: A systematic review of the research literature. American Journal of Community Psychology, 58(1-2), 174-191. https://doi.org/10.1002/ajcp.12074.

Waterman, A. S. (2007). On the importance of distinguishing hedonia and eudaimonia when contemplating the hedonic treadmill. American Psychologist, 62(6), 612-613. https://doi.org/10.1037/0003-066X62.6.612.

Wren, T. (2014). Philosophical moorings. In L. Nucci, D. Narvez, \& T. Krettenauer (Eds.), Handbook of moral and character education (2nd ed., pp. 11-29). Routledge.

Yeager, D. S. (2017). Social and emotional learning programs for adolescents. The Future of Children, 27(1), 73-94.

Zeldin, S. (2000). Integrating research and practice to understand and strengthen communities for adolescent development: An introduction to the special issue and current issues. Applied Developmental Science, 4(S1), 2-10.

Zief, S. G., Lauver, S., \& Maynard, R. (2006). Impacts of after-school programs on student outcomes: A systematic review. Campbell Systematice Reviews. https:// doi.org/10.4073/csr.2006.3. 
Open Access This chapter is licensed under the terms of the Creative Commons Attribution 4.0 International License (http://creativecommons.org/licenses/by/4.0/), which permits use, sharing, adaptation, distribution and reproduction in any medium or format, as long as you give appropriate credit to the original author(s) and the source, provide a link to the Creative Commons license and indicate if changes were made.

The images or other third party material in this chapter are included in the chapter's Creative Commons license, unless indicated otherwise in a credit line to the material. If material is not included in the chapter's Creative Commons license and your intended use is not permitted by statutory regulation or exceeds the permitted use, you will need to obtain permission directly from the copyright holder.

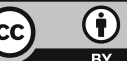

